\title{
How to The Impact on Transformational Leadership Style and Job Motivation On Organizational Citizenship Behaviour (OCB) With Job Satisfaction as Mediating Variables at Outsourcing Company
}

\author{
Agus Arijanto ${ }^{1}$ \\ ${ }^{1}$ Economic \& Business Faculty, Universitas Mercu Buana Jakarta, and Postgraduate Student at The Programme \\ of Doctor of Management Science Universitas Jenderal Soedirman Purwokerto Central Java, Indonesia \\ 1'agus.arijanto@mercubuana.ac.id \\ DOI: 10.47760/cognizance.2022.v02i01.001
}

\begin{abstract}
This study aims to analyze the effect of transformational leadership style and work motivation on employee organizational citizenship behavior (OCB) mediated by employee job satisfaction. The object of the research is employees of PT. Sumberdaya Dian Mandiri with a sample of 95 people. Methods of data collection using questionnaire data collection and library research. Data analysis method using Partial Least Square. The result of this study show that (1) transformational leadership has a positive but not significant effect on organizational citizenship behavior (OCB); (2) work motivation has a positive and significant effect on organizational citizenship behavior (OCB); (3) transformational leadership has a positive and significant effect on job satisfaction; (4) work motivation has a positive and significant effect on job satisfaction; (5) job satisfaction has a positive but not significant effect on organizational citizenship behavior (OCB); (6) job satisfaction in mediating transformational leadership on organizational citizenship behavior $(O C B)$ has a positive but not significant effect, and (7) job satisfaction in mediating work motivation on organizational citizenship behavior $(O C B)$ has a positive and significant effect.
\end{abstract}

Keywords: Transformational Leadership, Work Motivation, Job Satisfaction, Organizational Citizenship Behavior (OCB)

\section{INTRODUCTION}

The development of globalization has resulted in increasingly rapid competition in the business world. The company certainly chooses employees who have good behavior and can be relied on so that they can carry out their duties to the maximum. In today's dynamic world of work, flexibility is very important. Organizations want employees who are willing to perform tasks that are not listed in their job descriptions. Paramita (2012) said that Organizational Citizenship Behavior (OCB) is a deep contribution that exceeds the demands of the role at work and is rewarded by the acquisition of task performance. According to Adnyani (2015), the small things that shape OCB behavior are the key to the success of an organization. When the reciprocity felt by employees is not as expected or unfair, employees will likely lose interest in displaying OCB behavior.

On the other hand, one of the factors that influence the success of an organization is leadership style. Widayati et al., (2017) say that a leader must have power and authority in governing subordinates to achieve the goals set by the company, so naturally, a leader is required to have more skills and intelligence than his subordinates. Transformational leaders are leaders who inspire followers to put aside personal interests for the good of the organization and they can have a tremendous influence on their followers (Sunyoto \& Burhanudin, 2015).

The company also realizes that employee motivation is very influential on the company's growth rate. This is reinforced by Widayati et al., (2017) that one of the factors that influence the success of a company is processing human resources. These human resources are the main driver in the company's operations and play a very important role in advancing the company. The company does not only expect capable, capable, and skilled employees, but also they are willing to study hard and have the desire to achieve optimal work results. Motivation for employees is useful for increasing enthusiasm and morale, so employees will have motivation 
according to their abilities if the company can meet the needs of these employees. According to Mahesa (2010) motivation is an impulse that moves people to behave to fulfill certain goals.

Meanwhile, an employee's job satisfaction is influenced by the way the leader leads his employees. A good leader can utilize the existing human resources in the company well, so that leadership is an important part of increasing employee job satisfaction. According to Herminingsih A, (2020), transformational leadership significantly affects employee job satisfaction. This is in line with Robbins \& Judge (2015) which states that transformational leadership encourages employees to perform well and have good job satisfaction.

According to Amin \& Saleh (2014), employee satisfaction with work is considered one of the main factors for the success and survival of the organization. Job satisfaction is a positive emotional state resulting from evaluating one's work as an achievement or facilitating the achievement of one's work values (Guido, 2017). Robbins (2010) says that satisfied employees are more likely to speak positively about the organization, help others, and far exceed normal expectations at work, and be more proud to exceed task demands because employees want to reciprocate their positive experiences. Given that job satisfaction at least captures a positive mood in the workplace, it is likely that employees will show OCB when they experience high levels of job satisfaction (McNeely \& Meglino in Guido, 2017).

Hypothesis

Transformational leadership can make subordinates more involved and concerned about their work, devote more attention and time to their work, and become less attentive to their interests. Leaders who exhibit this kind of behavior are more liked and trusted by their subordinates. The liking and trust of the subordinates will increase the additional effort of the subordinates, to achieve the goals that have been set. When employees work well in the organization, it can benefit the organization in competition, and provide trust and motivation for the employees themselves. That way it can also produce employees who are expected to become good employees. These good employees tend to display a good attitude or what is called OCB Behavior. (Jamshed,2017)

Jamshed (2017) explains that leaders can play an important role in improving the Organizational Citizenship Behavior (OCB) of employees. Transformational leaders enhance the Organizational Citizenship Behavior (OCB) of their followers by inspiring and motivating them to put in the extra effort. In a study by Choudhary, Kumar, and Philip (2016) about the influence of transformational leadership on followers of Organizational Citizenship Behavior (OCB). Jamshed's research, 2017 states that transformational leadership has a significant effect on OCB. Hassi, 2018 stated that transformational leadership was also found to affect OCB among employees. Based on the description above, the proposed hypothesis is as follows:

H1: Transformational leadership has a positive and significant effect on Organizational Citizenship Behavior (OCB). The results of data analysis conducted by Febriani, (2016) in the journal Effect of work motivation on organizational citizenship behavior (OCB) of employees of PT. Pelindo III (Persero) Tanjung Perak Surabaya branch shows that work motivation as measured by three indicators, namely behavioral direction, level of effort, and level of persistence has a positive and significant influence on employee organizational citizenship behavior.

Supporting the development and goals of the company so that employees establish good relations with their co-workers, obey the work rules set by the company, never skip work or are absent without notification, and at work, everyday employees are always present on time. On the other hand, the behavior direction of employees who do not have low work motivation in their behavior hinders the smooth running of the company in achieving its goals. Based on the description above, the proposed hypothesis is as follows:

H2: The influence of work motivation on Organizational Citizenship Behavior (OCB) has a positive and significant effect. Hughes et al. (2012:542) suggest that transformational leaders have good views and communication skills and can use them to maintain the relationship between leaders and their subordinates. Transformational leaders will be more successful in encouraging organizational change because they can influence the emotions of their subordinates and can encourage employee willingness to work to be able to realize the vision of their leader. The leaders expected by company employees are leaders who can provide job satisfaction for their employees so that employees are encouraged to give more than their responsibilities or Organizational Citizenship Behavior (OCB) to the company. According to Wicker (2011), job satisfaction is a sense of pride and inner satisfaction that is achieved when someone can do a certain job. Dissatisfied employees tend to avoid duties and responsibilities so that they can interfere with the process of achieving company goals (Indrawan and Dewi, 2014). Diaksa and Dewi (2014) are of the view that companies should pay attention to the number of bonuses received by employees, the number of bonuses should be given by the performance and workload of employees. Guido's research, 2017 states that job satisfaction has a positive influence in mediating the relationship between transformational leadership behavior and OCB. 
Based on the description above, the proposed hypothesis is as follows:

H3: The effect of transformational leadership on Organizational Citizenship Behavior (OCB) mediated by job satisfaction has a positive and significant effect. Farlen (2011) explains that work motivation is something that gives rise to work motivation or enthusiasm or in other words, it drives morale that results in job satisfaction. Zare-Khafri and Hasani (2014) state that job satisfaction creates a positive affective status in the organization, which is related to social and participatory behavior.

Those who have more job satisfaction in an organization will introduce behavior which can be in the form of Organizational Citizenship Behavior (OCB) because their interaction with the organization has given them job satisfaction. Based on the description above, the proposed hypothesis is as follows:

H4: The effect of work motivation on organizational citizenship behavior (OCB) mediated by job satisfaction has a positive and significant effect. Someone who has satisfaction at work will have a willingness to do things that are more outside of his formal responsibilities. This willingness became known as Organizational Citizenship Behavior (OCB). In simple terms, it can be understood that when individuals are satisfied with their work, the resulting Organizational Citizenship Behavior (OCB) is a form of individual appreciation for the organization where the individual works and has given a sense of satisfaction to the individual.

Research conducted by Mahendra (2010) shows that there is a positive and significant influence between job satisfaction on Organizational Citizenship Behavior (OCB). Research conducted by Rohayati (2014) states that the variable job satisfaction has a positive and significant effect on Organizational Citizenship Behavior (OCB). This means that the level of Organizational Citizenship Behavior (OCB) is a result of the high and low quality of ongoing job satisfaction. Hakim et al, 2017 in their research stated that transformational leadership affects OCB

H5: The effect of job satisfaction on Organizational Citizenship Behavior (OCB) has a positive and significant effect.

\section{Material AND Method}

The research design in this study is a combination of explanatory, descriptive, and quantitative research. The explanatory research method was used because in this study the relationship between the variables studied was explained using the PLS-SEM (Partial Least Square-Structural Equation Modeling) method. According to Sugiono (2019), explanatory research aims to describe a generalization or explain the relationship between one variable and another.

The population in this study were employees of this outsourcing company (PT.Sumberdaya Dian Mandiri) with a sample of 95 employees determined by the census sampling technique. The census technique is the use of the entire population without having to draw a research sample as a unit of observation. Data collection techniques in this study using questionnaires and literature study. The questionnaire is a list of questions made by researchers aimed at respondents to obtain primary data related to research (Sugiyono 2019). While library research is a method of collecting data taken from library sources, both from books, research journals, and articles that function to support and complement primary data in the field. The data analysis method used in this study uses Component or Variance Based Structural Equation Modeling which in data processing uses the Partial Least Square (Smart-PLS) version 3.0 program.

\section{III.RESULT}

According to Septiyandi, 2018 before testing the hypothesis to predict the relationship between latent variables in structural capital, testing the measurement model must first be done to verify indicators and latent variables. This test includes construct validity testing and constructs reliability testing.

Validity test

The validity test aims to measure and show the level of reliability and validity of the DTOs to get valid data. 


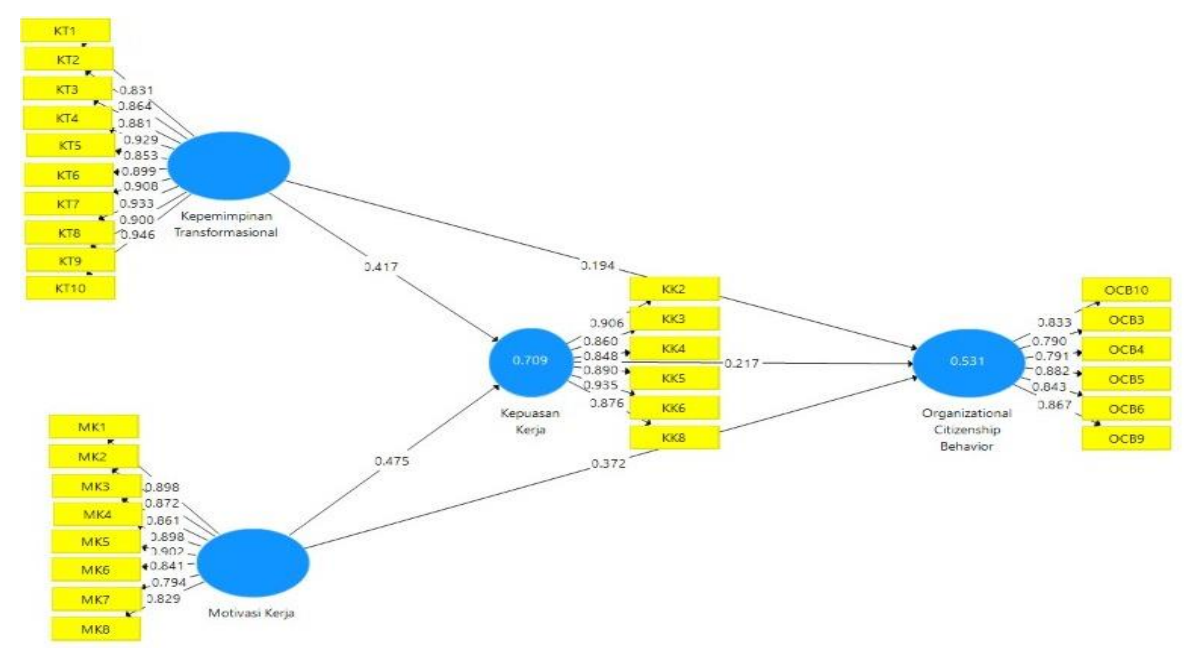

Figure 1. Results of the PLS algorithm

According to Ghozali (2014), an indicator is said to be valid if its value is greater than 0.70 . While the loading factor below 0.70 will be removed from the model. Based on the convergent validity test in the figure, it can be seen that all indicators of each construct have a loading factor above 0.70 , so it can be concluded that the indicator is declared valid and meets the criteria for convergent validity.

Reliability Test

The reliability test was carried out to prove the accuracy, consistency, and accuracy of the instrument in measuring constructs (Ghozali, 2015). The reliability test was carried out using Composite Reliability and Cronbach's Alpha tests by looking at all values of latent variables that had Composite Reliability and Cronbach's Alpha values 0.70 .

Table 1. Composite Reliability Test Results and Cronbach's Alpha

\begin{tabular}{lcc}
\hline \multicolumn{1}{c}{ Construct } & Composite Reliability & Cronbach's Alpha \\
\hline Transformational Leadership & 0,976 & 0,972 \\
\hline Motivation & 0,954 & 0,946 \\
\hline Work Satisfaction & 0,952 & 0,943 \\
\hline $\begin{array}{l}\text { Organizational Citizenship } \\
\text { Behavior }(O C B)\end{array}$ & 0,935 & 0,923 \\
\hline
\end{tabular}

Source: output Smart PLS 2021

Inner Model Test

According to Ghozali (2015), the inner model aims to predict the relationship between latent variables. The inner model test is the development of a concept and theory-based model to analyze the relationship between exogenous and endogenous variables which has been described in a conceptual framework.

Table 2. Test Results for R-Square. Value

\begin{tabular}{lc}
\hline \multicolumn{1}{c}{ Endogen Variables } & R-Square \\
\hline Work Satisfaction & 0,709 \\
\hline $\begin{array}{l}\text { Organizational Citizenship Behavior } \\
(\text { OCB })\end{array}$ & 0,531 \\
\hline
\end{tabular}

Source: Output Smart PLS, 2021

From table 2 above, it can be seen that the value of R-Square (R2) or the coefficient of determination of job satisfaction is 0.709 . These results indicate that the endogenous variable of job satisfaction can be explained by exogenous variables, namely transformational leadership and work motivation by $70.9 \%$ while the 
remaining $29.1 \%$ is explained by other exogenous variables. It can also be seen that the value of R-Square (R2) or the coefficient of determination of Organizational Citizenship Behavior (OCB) is 0.531. These results indicate that the endogenous variable Organizational Citizenship Behavior (OCB) can be explained by exogenous variables, namely transformational leadership, work motivation, and job satisfaction by $53.1 \%$ while the remaining $46.9 \%$ is explained by other exogenous variables. To see the hypothesized relationship between constructs, the researcher uses path coefficients. The results of testing the path coefficients are as follows:

Table 3. Test Results for Path Coefficients

\begin{tabular}{lcc}
\hline \multicolumn{1}{c}{ Constructs } & $\begin{array}{c}\text { Work } \\
\text { Satisfaction }\end{array}$ & $\begin{array}{c}\text { Organizational } \\
\text { Citizenship } \\
\text { Behavior (OCB) }\end{array}$ \\
\hline Transformational Leadership & 0,255555556 & 0.043 \\
\hline Motivation & & 0,265277778 \\
\hline Work Satisfaction & 0,379861111 & 0,255555556 \\
\hline $\begin{array}{l}\text { Organizational Citizenship } \\
\text { Behavior (OCB) }\end{array}$ & & \\
\hline
\end{tabular}

Data Source processed 2021

Table 3 shows that the test results of path coefficients have a range of 0.368 to 0.547 which indicates that all values have a positive relationship because they have a value close to +1 . To see the significance of the effect of transformational leadership style and work motivation on employee organizational citizenship behavior (OCB) mediated by job satisfaction, by looking at the value of the parameter coefficients and the statistical significance value. The results of the SmartPLS output using bootstrapping are:

Table 4. T-statistic (Bootstrapping) Value Test Results

\begin{tabular}{lc}
\hline \multicolumn{1}{c}{ Consruct } & $\begin{array}{c}\text { T Statistics } \\
(|\mathrm{O} / \mathrm{STDEV}|)\end{array}$ \\
\hline $\begin{array}{l}\text { Transformational Leadership }(\mathrm{X} 1) \text {-> OCB } \\
(\mathrm{Y})\end{array}$ & 0,24 \\
\hline Motivation $(\mathrm{X} 2)$-> OCB $(\mathrm{Y})$ & 2,029 \\
\hline $\begin{array}{l}\text { Transormational Leadership }(\mathrm{X} 1) \text {-> Work } \\
\text { Satisfaction }(\mathrm{Z})\end{array}$ & 3,129 \\
\hline Motivation $(\mathrm{X} 2)$-> Work Satisfaction $(\mathrm{Z})$ & 4,964 \\
\hline Work Satisfaction $(\mathrm{Z})$-> OCB (Y) & 1,666 \\
\hline
\end{tabular}

Source: Data processed 2021

Table 5 shows that the results of the T-Statistic test (bootstrapping) have a range of 0.240 to 4.964 . It can be concluded that the relationship of work motivation to OCB, the relationship of transformational leadership to job satisfaction, and work motivation to job satisfaction were found to be significant with a T-Statistic value above 1.96 , namely $2.029,3.12,9$, and 4.964. Meanwhile, the relationship of transformational leadership to OCB and the relationship of job satisfaction to OCB was found to be insignificant with a T-Statistic value below 1.96, namely 0.240 and 1.666 .

\section{Research Hypothesis Testing}

This hypothesis testing is conducted to determine whether the research hypothesis proposed in the model is accepted or rejected. To test the proposed hypothesis, it can be seen from the path coefficients and T-Statistic values through the bootstrapping procedure. 
Table 5. Results of Direct Effect Hypothesis Testing

\begin{tabular}{lccc}
\hline \multicolumn{1}{c}{ Research Hypothesis } & Original Sample & T Statistics $(|\mathrm{O} / \mathrm{STDEV}|)$ & \multicolumn{1}{c}{ Notes } \\
\hline $\begin{array}{l}\text { Transformational Leadership (X1) - } \\
>\text { OCB (Y) }\end{array}$ & 0.043 & 0,166666667 & $\begin{array}{l}\text { There is an influence that is } \\
\text { positive and not significant }\end{array}$ \\
\hline Motivation (X2) -> OCB (Y) & 0,265277778 & 2.029 & $\begin{array}{l}\text { There is influence a positive } \\
\text { and significant }\end{array}$ \\
\hline $\begin{array}{l}\text { Transformational Leadership (X1) - } \\
>\text { Work Satisfaction (Z) }\end{array}$ & 0,255555556 & 3.129 & $\begin{array}{l}\text { There is influence a positive } \\
\text { and significant }\end{array}$ \\
\hline $\begin{array}{l}\text { Motivation (X2) -> Work } \\
\text { Satisfaction (Z) }\end{array}$ & 0,379861111 & 4.964 & $\begin{array}{l}\text { There is influence a positive } \\
\text { and significant }\end{array}$ \\
\hline Work Satisfaction (Z) -> OCB (Y) & 0,255555556 & 1.666 & $\begin{array}{l}\text { There is an influence that is } \\
\text { positive and not significant }\end{array}$ \\
\hline Source: Data Proceed 2021 & & &
\end{tabular}

Table 6. Indirect Effect Hypothesis Testing Results

\begin{tabular}{lccl}
\multicolumn{1}{c}{ Research Hypothesis } & Original Sample & $\begin{array}{c}\text { T Statistics } \\
(\mid \mathbf{O} / \text { STDEV|) }\end{array}$ & Notes \\
\hline $\begin{array}{l}\text { K.Transformational Leadership (X1) - Work } \\
\text { Satisfaction (Z) - OCB (Y) }\end{array}$ & 0,094444444 & 1.542 & $\begin{array}{l}\text { There is an influence that is } \\
\text { positive and not significant }\end{array}$ \\
\hline $\begin{array}{l}\text { Motivation (X2) - Work Satisfaction (Z) - OCB } \\
\text { (Y) }\end{array}$ & 0,2625 & 3,244 & $\begin{array}{l}\text { There is a positive and } \\
\text { significant influence }\end{array}$ \\
\hline
\end{tabular}

Source processed 2021

\section{IV.DISCUSSION}

Based on the formulation of the problem that forms the basis of the research, the following is a discussion by the results of several tests that have been carried out:

1. The Effect of Transformational Leadership on Organizational Citizenship Behavior (OCB)

Based on the hypothesis test, it can be seen that the Original Sample value is 0.043 which is close to the value of +1 and has a T-statistic value of 0.240 (> 1.96), which means that transformational leadership has a positive effect on OCB but is not significant. The results of this study are supported by research by Aboramadan and Dahleez (2020) which proves that OCB has a positive influence on transformational leadership. In general, PT. Sumberdaya Dian Mandiri believes that to achieve excellence, individual performance must be as high as possible because basically, individual performance affects the performance of a team or workgroup and ultimately affects the overall performance of the organization.

2. The Influence of Work Motivation on Organizational Citizenship Behavior (OCB)

Based on the hypothesis test, it can be seen that the Original Sample value is 0.382 which is close to the +1 value and has a T-statistic value of 2.029 (> 1.96). So it can be concluded that work motivation has a positive and significant effect on organizational citizenship behavior (OCB). The results of this study strengthen the results of previous research proposed by Febriani (2016) in that work motivation can be measured through three indicators, namely the direction of behavior, the level of effort, and the level of persistence. These results are also supported by research by Paramita (2012). Organizational Citizenship Behavior (OCB) is a deep contribution that exceeds the demands of the role at work and is rewarded by the acquisition of task performance.

3. The Effect of Transformational Leadership on Job Satisfaction

Based on the hypothesis test, it can be seen that the Original Sample value is 0.368 which is close to the value of +1 and has a T-Statistic value of 3.129 (> 1.96). Thus, it can be concluded that transformational leadership has a positive and significant effect on job satisfaction. The results of this study strengthen the results of research conducted by Christoph Nohe and Guido Hertel (2017) that job satisfaction has a positive influence on the relationship to OCB. These results are also supported by the research of Patrick J. Valeau and Pascal Paillé 
(2017) that job satisfaction affects OCB. This is in line with what happened to PT. Resources Dian Mandiri when the leader gives what is expected by the subordinates there will be a sense of satisfaction in the subordinates and will voluntarily do the tasks and responsibilities given.

4. The Effect of Work Motivation on Job Satisfaction

Based on the hypothesis test in this study, it can be seen that the Original Sample value is 0.547 which is close to the value of +1 and has a T-Statistic value of 4.964 (> 1.96). This shows that work motivation has a positive and significant effect on job satisfaction. The results of this study strengthen the research results of Setiono et al., (2010) that motivation has a significant and positive correlation with job satisfaction. This is also in line with PT. Dian Mandiri resources when given encouragement or motivation to work, employees will feel satisfied at work and can work together in line with the company's vision and mission.

5. Effect of Job Satisfaction on Organizational Citizenship Behavior (OCB)

Based on the hypothesis test in the study, it can be seen that the Original Sample value is 0.368 which is close to the value of +1 and has a T-Statistic value of $1.666(<1.96)$. Thus, it can be concluded that job satisfaction has a positive and significant effect on job satisfaction. The results of this study strengthen the results of research conducted by Mahendra (2010) which shows that there is a positive and significant influence between job satisfaction on Organizational Citizenship Behavior (OCB). In addition, it is also supported by the results of research by Arimba et al., (2016) which states that job satisfaction has a positive effect on organizational citizenship behavior (OCB). In simple terms, it can be understood that when individuals are satisfied with their work, the resulting Organizational Citizenship Behavior (OCB) is a form of individual appreciation for the organization where the individual works and has given a sense of satisfaction to the individual.

6. The Effect of Transformational Leadership on Organizational Citizenship Behavior (OCB) through Job Satisfaction

Based on the hypothesis test in the study, it can be seen that the Original Sample value is 0.316 which is close to the value of +1 and has a T-Statistic value of 1.542 (> 1.96). Thus, it can be concluded that transformational leadership has a positive but not significant effect on OCB mediated by job satisfaction. It can be concluded that the existence of job satisfaction which mediates the relationship of transformational leadership to OCB has no effect (no mediation). Research by Hughes et al., (2012) states that transformational leaders will be more successful if leaders encourage organizational change because they can influence the emotions of their subordinates and can encourage employee willingness to work to be able to realize the vision of their leader is not in line with this study. Leaders expected by company employees are leaders who can provide job satisfaction for their employees so that employees are encouraged to give more than their responsibilities or Organizational Citizenship Behavior (OCB) to the company).

7. The Influence of Work Motivation on Organizational Citizenship Behavior (OCB) through Job Satisfaction

Based on the hypothesis test in the study, it can be seen that the Original Sample value is 0.378 which is close to +1 value and has a T-Statistic value of 3.244 (> 1.96) which means that it can be concluded that job satisfaction mediates the relationship between work motivation and OCB has an influence on mediate (partial mediation). These results are supported by research by Sunyoto (2012) which says that when motivation is given to employees or someone, of course, it has a purpose, namely encouraging employee enthusiasm and passion, increasing employee morale and job satisfaction, increasing employee productivity, maintaining employee loyalty and stability, increasing employee performance and increasing employee satisfaction. discipline and reduce employee absenteeism, create a good working atmosphere and relationship, increase employee creativity and participation, improve employee welfare, enhance employee's sense of responsibility towards their duties and work

\section{Conclusions}

Based on the analysis of the results of the research and discussion, it can be concluded that Transformational Leadership has a positive but not significant effect on Organizational Citizenship Behavior (OCB). Work Motivation has a positive and significant effect on Organizational Citizenship Behavior (OCB). Transformational Leadership has a positive and significant effect on Job Satisfaction. Work motivation has a positive and significant effect on job satisfaction. Job satisfaction has a positive and significant effect on Organizational Citizenship Behavior (OCB). Job satisfaction has a positive but not significant effect in mediating the relationship between Transformational Leadership and Organizational Citizenship Behavior (OCB). Job satisfaction plays a full role in mediating the relationship between Work Motivation and Organizational Citizenship Behavior (OCB). 
Then according to the results of the research that has been done, the researchers provide several suggestions, as follows:

1. The company should continue to maintain and improve the factors of work motivation and job satisfaction in the company to further encourage employees to behave OCB so that the company is expected to achieve the company's goals that have been set.

2. Management of the company should pay attention to transformational leadership factors, especially the leadership to instill a sense of pride in employees while joining the company. In addition, the leadership of PT. Dian Mandiri resources also need to pay attention to employees so that they can become role models in terms of self-development and fully contribute to the company.

3. To the management of the company should be able to be fair to all employees regardless of status, education level, and position so that employees have a disciplined attitude and responsibility in carrying out a given task.

4. It is recommended that the management of the company can provide clear directions on the company's provisions so as not to hinder employees from developing themselves and being able to see the potential in employees.

\section{REFERENCES}

[1]. Aboramadan, M. (2020). Leadership styles and employees' work outcomes in non-profit organizations: the role of work engagement. Journal of Management Development.

[2]. Amin, Rashidah, Mohamad I.A., \& Salleh, Munir. (2014). The Link Between LeaderMember Exchange, Organizational Citizenship Behavior and Job Satisfaction: A Case Study on Local Government. International Journal of Academic Research in Business and Social Sciences.

[3]. Febriani, H.D. (2016). The effect of work motivation on Organizational citizenship behavior (OCB) of employees of PT. Pelindo III (Persero) Tanjung Perak Surabaya branch. Journal of Administrative Applications. Vol.19 No. 2

[4]. Guido, H. (2017). Transformational Leadership and Organizational Citizenship Behavior: A MetaAnalytic Test of Underlying Mechanisms. Frontiers in Psychology. Retrieved from https://dx.doi.org/10.3389\%2Ffpsyg.2017.01364 Hughes. (2012). Leadership: Enriching Lessons From Experience, Seventh Edition. Jakarta: Salemba Humanika. Retrieved from https://doi.org/10.1515/mmcks-2017-0034 Mahesa, Deewar. (2010).

[5]. Guido, H. (2017). Transformational Leadership and Organizational Citizenship Behavior: A MetaAnalytic Test of Underlying Mechanisms. Frontiers in Psychology. Retrieved from https://dx.doi.org/10.3389\%2Ffpsyg.2017.01364

[6]. Herminingsih, A. (2020). Transformational leadership positive influence on employee engagement through job satisfaction and its effect on improving organizational commitment. Journal of Service Management and Marketing, 13(2), 281-296.

[7]. Herminingsih, Anik. (2014). Budaya Organisasi. Andi (Penerbit).

[8]. Hughes. (2012). Leadership: Enriching Lessons From Experience, Seventh Edition. Jakarta: Salemba Humanika. Retrieved from https://doi.org/10.1515/mmcks-2017-0034

[9]. Luthans, Fred. (2006). Organizational Behavior. (Translated by V.A Yuwono, et al), Indonesian Edition, Yogyakarta: ANDI.

[10].Mahesa, Deewar. (2010). Analysis of the Effect of Motivation and Job Satisfaction on Employee Performance with Length of Work as Moderating Variable (Study at PT. Coca Cola Amatil Indonesia (Central Java). Thesis of the Faculty of Economics, Diponegoro University, Semarang.

[11]. Moorhead, Gregory and Ricky W. Griffin. (2013). Organizational behavior. Salemba Four. Jakarta.

[12].Neubert, J, Mitchell; Katie Halbesleben. (2015). Called to Commitment: An Examination of Relationships Between Spiritual Calling, Job Satisfaction, and Organizational Commitment. Journal Business Ethics, 132:859-872.

[13].Paramita, \& Patricia, Diana. (2012). Organizational Citizenship Behavior (OCB): Aspects Of Individual Activities At Work. Septyandini, Fitri. (2018). The Influence of Transformational Leadership Style and Organizational Culture on Employee Performance with Rewards as Moderating Variables. Mercu Buana University.

[14].Robbins, Stephen P. (2008). Organizational behavior. Tenth Edition. Complete Edition. Index Publisher. Jakarta. Safitri, Dini .(201 7). The Influence of Leadership and Organizational Commitment 
on Job Satisfaction and Employee Performance of PT Ramajaya Pramukti, Tapung District, Kampar Regency, Riau Province. JOM FEKON, Vol. 4 No.2. Pg (3528-3542).

[15].Siagian, Sondang P, (2006), Organizational Leadership and Administrative Behavior, Mount Agung Publishers, Jakarta.

[16].Sugiono. (2018). Qualitative Quantitative Research Methods and R\&D. Bandung: Alphabeta

[17].Sugiyono. (2011). Business Research Methods. Eleventh Print. Bandung: CV Alfabeta.

[18].Widayati, C., Rahardjo, Thea, H., Febriyanti, Melly. (2017). The Influence of Transformational Leadership Style, Motivation and Compensation on Employee Performance. Journal of Economics, 22 (03), 466-485

[19].Wibowo. (2010), Performance Management, Rajawali Press, Jakarta. Widagdo., et al. (2013), Effect of Organizational Culture and Organizational Commitment on Employee Job Satisfaction at PT. Nutrifood Indonesia In Jakarta. Indonesian Science Management Research Journal (JRMSI), Vol.4, No.1. Yukl, G. (2010). Leadership in Organizations. Prentice-Hall. New Jersey.

[20].Mochamad Soelton, Muhammad Atnani. (2018), How Work Environment, Work Satisfaction, Work Stress on The Turnover Intention Affect University Management, Indonesian Business Management Journal, Vol. 5, No. 3

[21].Ni Luh Lia Paramita Dewi, I Wayan Bagia, Ni Made Suci, (2017), The Effect of Transformational Leadership and Organizational Commitment on Employee Job Satisfaction at PT PLN (Persero) Rayon Singaraja, Indonesian Management Journal, Vol 8, No 2.

[22].Northouse, P. G. (2013). Leadership. Theory and practice. Sixth edition Jakarta: PT. Index.

[23].Pongpearchan, P.(2016). "Effect of transformational leadership on strategic Human Resources Management and firm success of Toyota's Dealer in Thailand'. Journal of business and retail management research. Vol.10, Issue 2, pp. 53-63.

[24].Zainal, Veithzal Rivai., Muliaman Darmansyah Hadah., and H. Mansyur Ramly. (2014). Leadership and Organizational Behavior. Fourth Edition. Jakarta. PT. King Grafindo Persada. 